\title{
Article \\ Coupling between Source Rock and Reservoir of Shale Gas in Wufeng-Longmaxi Formation in Sichuan Basin, South China
}

\author{
Yuying Zhang ${ }^{1,2,3}{ }^{(D}$, Shu Jiang ${ }^{1,2,3, *}$, Zhiliang He ${ }^{4, *}$, Yuchao Li ${ }^{5}$, Dianshi Xiao ${ }^{6}$, Guohui Chen ${ }^{1,2,3}$ \\ and Jianhua Zhao ${ }^{6}$
}

check for

updates

Citation: Zhang, Y.; Jiang, S.; He, Z.; Li, Y.; Xiao, D.; Chen, G.; Zhao, J. Coupling between Source Rock and Reservoir of Shale Gas in WufengLongmaxi Formation in Sichuan Basin, South China. Energies 2021, 14, 2679. https://doi.org/10.3390/ en14092679

Academic Editor: José A. Torres

Received: 22 March 2021

Accepted: 29 April 2021

Published: 7 May 2021

Publisher's Note: MDPI stays neutral with regard to jurisdictional claims in published maps and institutional affiliations.

Copyright: (c) 2021 by the authors. Licensee MDPI, Basel, Switzerland. This article is an open access article distributed under the terms and conditions of the Creative Commons Attribution (CC BY) license (https:// creativecommons.org/licenses/by/ $4.0 /)$.
1 Key Laboratory of Tectonics and Petroleum Resources, Ministry of Education, China University of Geosciences, Wuhan 430074, China; zhangyuying@cug.edu.cn (Y.Z.); chenguohui@s.upc.edu.cn (G.C.)

2 Key Laboratory of Theory and Technology of Petroleum Exploration and Development in Hubei Province, Wuhan 430074, China

3 School of Earth Resources, China University of Geosciences, Wuhan 430074, China

4 State Key Laboratory of Shale Oil and Gas Enrichment Mechanisms and Effective Development, SINOPEC, Beijing 100083, China

5 Liaoning Geological and Mineral Survey Institute Co. LTD., Shenyang 110032, China; lyccug@163.com

6 School of Geosciences, China University of Petroleum (East China), Qingdao 266580, China; xiaods@upc.edu.cn (D.X.); zhaojh@upc.edu.cn (J.Z.)

* Correspondence: jiangsu@cug.edu.cn (S.J.); hezhiliang@sinopec.com (Z.H.)

\begin{abstract}
In order to analyze the main factors controlling shale gas accumulation and to predict the potential zone for shale gas exploration, the heterogeneous characteristics of the source rock and reservoir of the Wufeng-Longmaxi Formation in Sichuan Basin were discussed in detail, based on the data of petrology, sedimentology, reservoir physical properties and gas content. On this basis, the effect of coupling between source rock and reservoir on shale gas generation and reservation has been analyzed. The Wufeng-Longmaxi Formation black shale in the Sichuan Basin has been divided into 5 types of lithofacies, i.e., carbonaceous siliceous shale, carbonaceous argillaceous shale, composite shale, silty shale, and argillaceous shale, and 4 types of sedimentary microfacies, i.e., carbonaceous siliceous deep shelf, carbonaceous argillaceous deep shelf, silty argillaceous shallow shelf, and argillaceous shallow shelf. The total organic carbon (TOC) content ranged from $0.5 \%$ to $6.0 \%$ (mean $2.54 \%$ ), which gradually decreased vertically from the bottom to the top and was controlled by the oxygen content of the bottom water. Most of the organic matter was sapropel in a high-over thermal maturity. The shale reservoir of Wufeng-Longmaxi Formation was characterized by low porosity and low permeability. Pore types were mainly $<10 \mathrm{~nm}$ organic pores, especially in the lower member of the Longmaxi Formation. The size of organic pores increased sharply in the upper member of the Longmaxi Formation. The volumes of methane adsorption were between $1.431 \mathrm{~m}^{3} / \mathrm{t}$ and $3.719 \mathrm{~m}^{3} / \mathrm{t}$, and the total gas contents were between $0.44 \mathrm{~m}^{3} / \mathrm{t}$ and $5.19 \mathrm{~m}^{3} / \mathrm{t}$, both of which gradually decreased from the bottom upwards. Shale with a high TOC content in the carbonaceous siliceous/argillaceous deep shelf is considered to have significant potential for hydrocarbon generation and storage capacity for gas preservation, providing favorable conditions of the source rock and reservoir for shale gas.
\end{abstract}

Keywords: Wufeng-Longmaxi Formation; Sichuan Basin; source rock; reservoir; shale gas

\section{Introduction}

During the Late Ordovician to Early Silurian, massive black shale ("hot shale") was deposited worldwide under the shelf and epicontinental environment with sea levels rising due to melting icebergs [1-3]. The Wufeng-Longmaxi Formation black shale (WLBS) in the Sichuan Basin are the equivalent strata of hot shale in south China, which are the main target strata for shale gas exploration and development in China [4,5]. The proved shale gas reserves in the WLBS exceed $5000 \times 10^{8} \mathrm{~m}^{3}$ [6]. The strata in the upper Ordovician-lower 
Silurian is one of the most widely developed high-quality source rocks in the world. The shale of the Wufeng-Longmaxi Formation deposited during this period in South China has a high content of organic matter and stable lateral distribution [7-9]. Shale gas reservoirs are characterized by low porosity and low permeability, with small pore size and abundant nanopores (about $10 \mathrm{~nm}$ in diameter) [10].

At present, significant breakthroughs have been achieved in shale gas exploration in the Sichuan Basin (e.g., in Fuling, Weiyuan-Changning), and the largest shale gas field in China has been built in Fuling. Previous studies have proved that the enrichment of marine shale gas in South China is mainly controlled by 3 factors: (1) shale in the deep shelf provided the material basis for shale gas generation [7,11-13]; (2) the moderate thermal evolution was conducive to the formation of organic pores, which provided available storage spaces for shale gas [14-16]; (3) the favorable preservation condition is the key condition for the enrichment of shale gas $[17,18]$. As an unconventional resource, shale gas was generated and accumulated in organic-rich shale; thus, organic-rich shale is considered as both the resource rock and reservoir [19-21].

However, previous research on shale was mainly focused on the source rock or reservoirs separately, e.g., the quantity of hydrocarbon generation or quality of reservoirs. In recent work, overwhelming evidence proves that high organic content and high porosity appear simultaneously in shale [15,22-24], which is different from a conventional oil-gas reservoir. The geological characteristics of shale could determine the material basis for shale gas generation, as well as provide storage space for shale gas preservation $[25,26]$. Therefore, the favorable combination of hydrocarbon source rock and reservoir is an important condition for shale gas accumulation. However, the study on the coupling characteristics of shale gas source rocks and reservoirs is still insufficient and needs more detailed work.

In this study, the heterogeneous characteristics of organic and inorganic components in the source rock and reservoir of the WLBS in the Sichuan Basin are discussed in detail, based on petrology, sedimentology, reservoir physical properties, and gas content. On this basis, the effect of coupling between the source rock and reservoir on shale gas generation and reservation was analyzed. It would be helpful to analyze the main factors controlling shale gas accumulation and to predict the potential zone for shale gas exploration.

\section{Materials and Methods}

A total of 173 samples were collected from cores of well A for various experiments and 26 samples from other wells in the Sichuan Basin (Figure 1) for capturing scanning electron microscope (SEM) images and focused ion beam (FIB) SEM images. Rock thin sections were performed at the Geological Exploration and Development Research Institute, Experimental Research Center, Chuanqing Drilling Engineering Co., LTD, CNPC, Chuanqing, China. The SEM images were made at the State Key Laboratory of Biochemical Engineering, Institute of Process Engineering, Chinese Academy of Sciences, and at the State Key Laboratory of Shale Oil and Gas Enrichment Mechanisms and Effective Development, SINOPEC. Three-dimensional FIB SEM images were made at China University of Petroleum (Beijing, China). Physical properties in the reservoir were determined at the State Key Laboratory of Oil and Gas Reservoir Geology and Exploitation, Chengdu University of Technology. Physical properties in the reservoir were determined at the State Key Laboratory of Oil and Gas Reservoir Geology and Exploitation, Chengdu University of Technology. The threedimensional FIB SEM images were made with a FEI-Helios NanoLab 650 under the testing condition of $30.0 \mathrm{KV}$ and $9.3 \mathrm{nA}$ (I-beam), 5.0 KV and $0.4 \mathrm{nA}$ (E-beam). The experiment of mineral composition was conducted at National Geological Testing Center. The data of mineral composition were measured with D8 ADVANCE XRD Diffractometer by the individual spectra of the anticipated mineral components. Organic geochemical analyses were performed at SINOPEC. The kerogen was extracted from shale samples through acid dissolving ( $\mathrm{HCl}$ and $\mathrm{HF}$ ) and drying, which was used to test organic carbon isotopes and organic types. The experiment of kerogen carbon isotope with GC-C-IRMS (DELTA 
plus XL C003) based on the methods of GB/T18340.2-2010, at the State Key Laboratory of Shale Oil and Gas Enrichment Mechanisms and Effective Development of SINOPEC. The experiment of gas adsorption was conducted at the Langfang Institute, Research Institute of Petroleum Exploration and Development, CNPC. The gas adsorption of ground samples (80-100 mesh) were performed with ISO-200 Gas Sorption Analyzer under $30^{\circ} \mathrm{C}$ using $>99.9 \%$ methane.

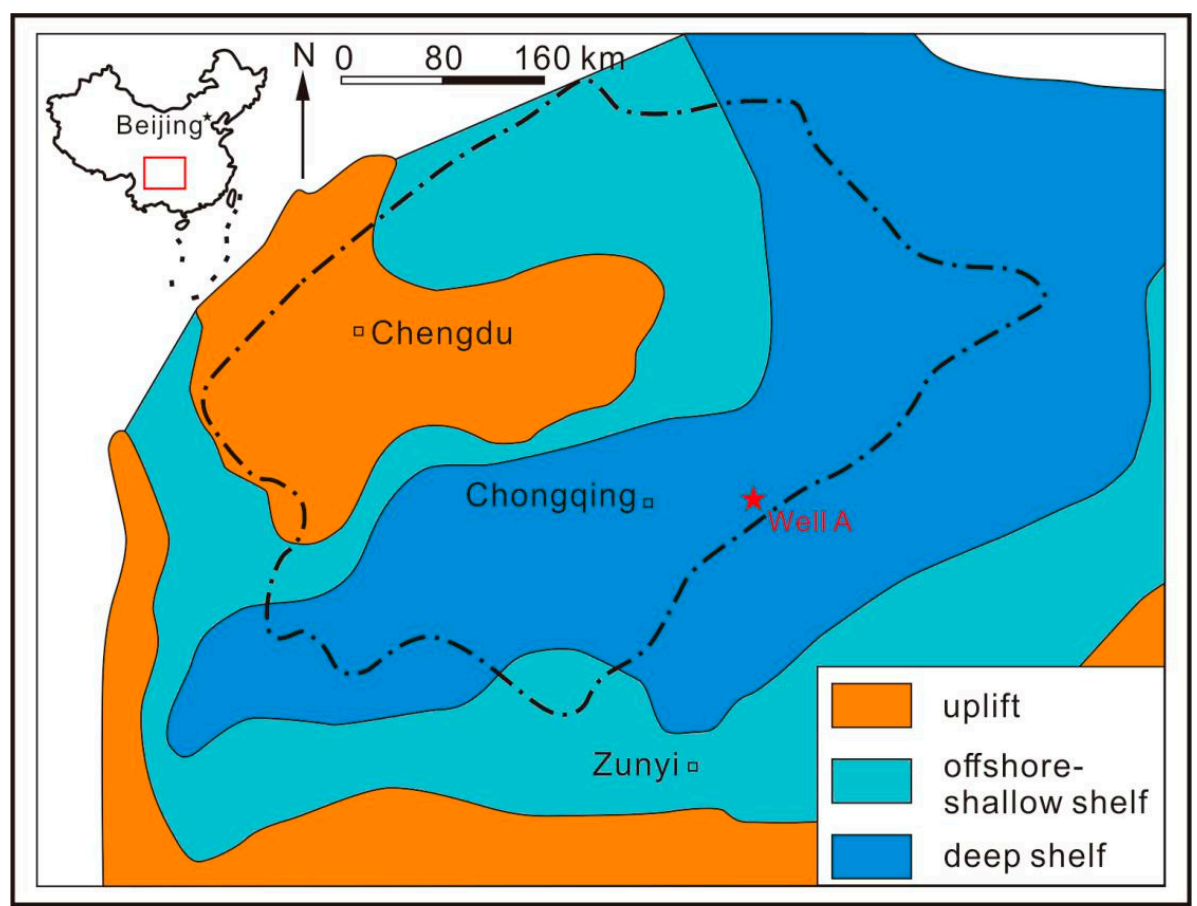

Figure 1. Simplified paleogeographic map of South China during the Ordovician-Silurian transition [27].

\section{Results}

3.1. Testing Data

\subsubsection{Mineral Composition}

Based on the data of mineral composition, quartz was determined to be the dominated mineral composition in the WLBS (from 30-70\%, with an average of $42 \%$ ), followed by clay minerals (from $20-50 \%$, with an average of $36 \%$ ), with a small amount of carbonate minerals (Figure 2).

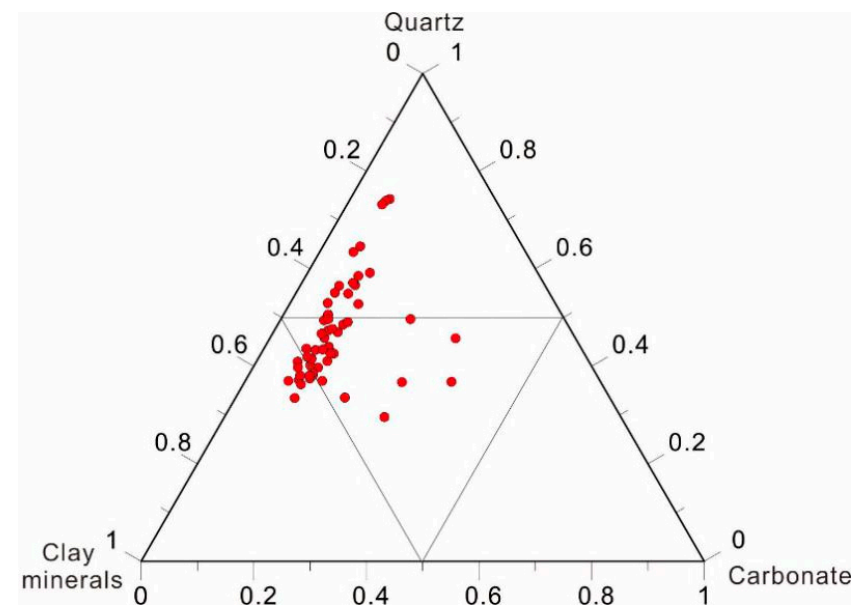

Figure 2. Ternary diagrams of mineral compositions in the Wufeng-Longmaxi Formation from Well A. 


\subsubsection{Organic Geochemistry}

The values of vitrinite reflectance (Ro) from nine samples in Well A ranged from $2.2 \%$ to $3.13 \%$, and the values of $\delta^{13} \mathrm{C}_{\text {org }}$ are $-29.2 \%$ and $-29.3 \%$, respectively (Figure 3 , Table 1). The values of total organic carbon (TOC) in WLBS of Well A basically ranged from $0.5 \%$ to $6.0 \%$ (about $2.54 \%$ on average) and gradually decreased vertically from the bottom to the top (Figure 3).

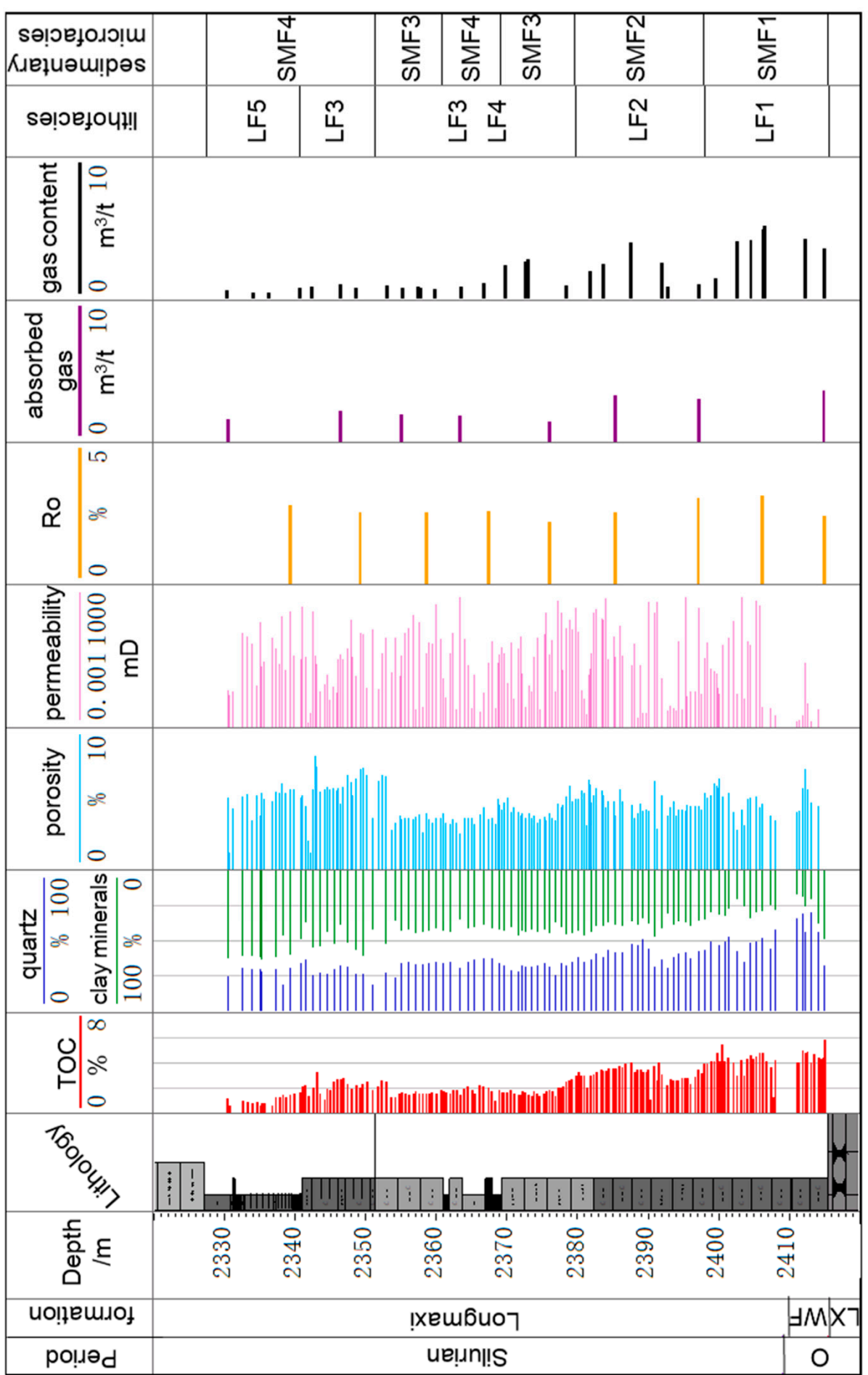

Figure 3. Comprehensive column of coupling between source rock and reservoir of WufengLongmaxi Formation in Well A. O: Ordovician, WF: Wufeng, LX: Linxiang, TOC: total organic carbon, Ro: vitrinite reflectance; LF: lithofacies; SMF: sedimentary microfacies. 
Table 1. Organic geochemical data of Wufeng-Longmaxi Formation in Well A.

\begin{tabular}{cccc}
\hline Depth $(\mathbf{m})$ & Formation & Ro $(\mathbf{\%})$ & $\boldsymbol{\delta}^{\mathbf{1 3}}$ Corg $\mathbf{( \% \mathbf { } )}$ \\
\hline 2339.33 & Longmaxi & 2.80464 & -29.2 \\
2349.23 & Longmaxi & 2.56699 & -29.3 \\
2358.6 & Longmaxi & 2.53983 & \\
2367.4 & Longmaxi & 2.58057 & \\
2376.1 & Longmaxi & 2.20033 & \\
2385.4 & Longmaxi & 2.53983 & \\
2397.1 & Longmaxi & 3.06266 & \\
2406.2 & Longmaxi & 3.13056 & \\
2414.9 & Wufeng & 2.4244 & \\
\hline
\end{tabular}

\subsubsection{Reservoir Properties}

The porosity of the WLBS in Well A ranged from $1.17 \%$ to $8.61 \%$ (mean $4.78 \%$ ), and the permeability was basically distributed between $0.0015 \mathrm{mD}$ and $335.21 \mathrm{mD}$ (Figure 3). On the whole, the reservoir of WLBS is characterized by low porosity and low permeability.

\subsubsection{Methane Adsorption}

With the increase of pressure in the experiment, the absorbed gas of methane in the shale reservoir increased gradually. The quantities of methane adsorption from Well A ranged between $1.42 \mathrm{~m}^{3} / \mathrm{t}$ and $3.66 \mathrm{~m}^{3} / \mathrm{t}$ under the maximum pressure of $10.83 \mathrm{MPa}$ (Table 2). The maximum adsorption of methane under equilibrium (Langmuir volume) was between $1.72 \mathrm{~m}^{3} / \mathrm{t}$ and $4.66 \mathrm{~m}^{3} / \mathrm{t}$ (Table 2), calculated by the Langmuir equation.

Table 2. Methane absorption data of Wufeng-Longmaxi Formation in Well A.

\begin{tabular}{|c|c|c|c|c|c|c|c|c|}
\hline \multirow{2}{*}{ Pressure (MPa) } & \multicolumn{8}{|c|}{ Absorbed Gas $\left(\mathrm{m}^{3} / \mathrm{t}\right)$} \\
\hline & $2330.46 \mathrm{~m}$ & $2346.5 \mathrm{~m}$ & $2355.13 \mathrm{~m}$ & $2363.4 \mathrm{~m}$ & $2376.05 \mathrm{~m}$ & $2385.42 \mathrm{~m}$ & $2397.13 \mathrm{~m}$ & $2414.88 \mathrm{~m}$ \\
\hline 0 & 0 & 0 & 0 & 0 & 0 & 0 & 0 & 0 \\
\hline 0.38 & 0.19 & 0.38 & 0.25 & 0.32 & 0.24 & 0.58 & 0.63 & 0.54 \\
\hline 1.04 & 0.5 & 0.75 & 0.7 & 0.67 & 0.56 & 1.34 & 1.16 & 1.29 \\
\hline 2.21 & 0.88 & 1.18 & 1.04 & 1.13 & 0.88 & 2.05 & 1.92 & 2.05 \\
\hline 4.28 & 1.23 & 1.71 & 1.47 & 1.45 & 1.12 & 2.68 & 2.46 & 2.9 \\
\hline 6.21 & 1.45 & 1.96 & 1.74 & 1.66 & 1.29 & 3.04 & 2.81 & 3.3 \\
\hline 8.67 & 1.58 & 2.14 & 1.9 & 1.79 & 1.38 & 3.17 & 3 & 3.57 \\
\hline 10.83 & 1.63 & 2.2 & 1.96 & 1.93 & 1.42 & 3.35 & 3.04 & 3.66 \\
\hline$V_{L}\left(m^{3} / t\right)$ & 2.22 & 2.76 & 2.56 & 2.34 & 1.72 & 4.00 & 3.64 & 4.66 \\
\hline
\end{tabular}

\section{Discussion}

\subsection{Types of Lithofacies}

An obvious positive relationship existed between quartz and TOC, in which the Pearson correlation coefficient was 0.7099 (Figure 4). In the vertical direction, the content of quartz gradually decreased from bottom to top, while the content of clay minerals gradually increased (Figure 3). Previous research believed that the quartz in the lower member of WLBS was mainly of biogenetic origin $[4,28]$, which could be proved by the picture of quartz with biogenic structure under the microscope (Figure 5a,b).

Lithofacies is a kind of rock or rock assemblage formed in a certain sedimentary environment. On the basis of the characteristics of the rock mineral composition, the TOC content, core descriptions (e.g., structure), and microscopic identification of rock thin sections (e.g., abundance of fossils), the WLBS in the study area was divided into 5 types of lithofacies as follows (Table 3). 


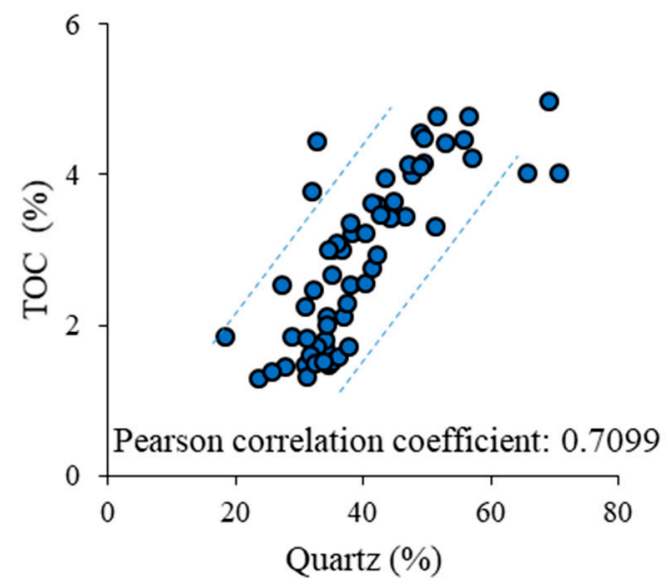

Figure 4. Scatter plot of total organic carbon (TOC) and quartz content in Wufeng-Longmaxi Formation from Well A.
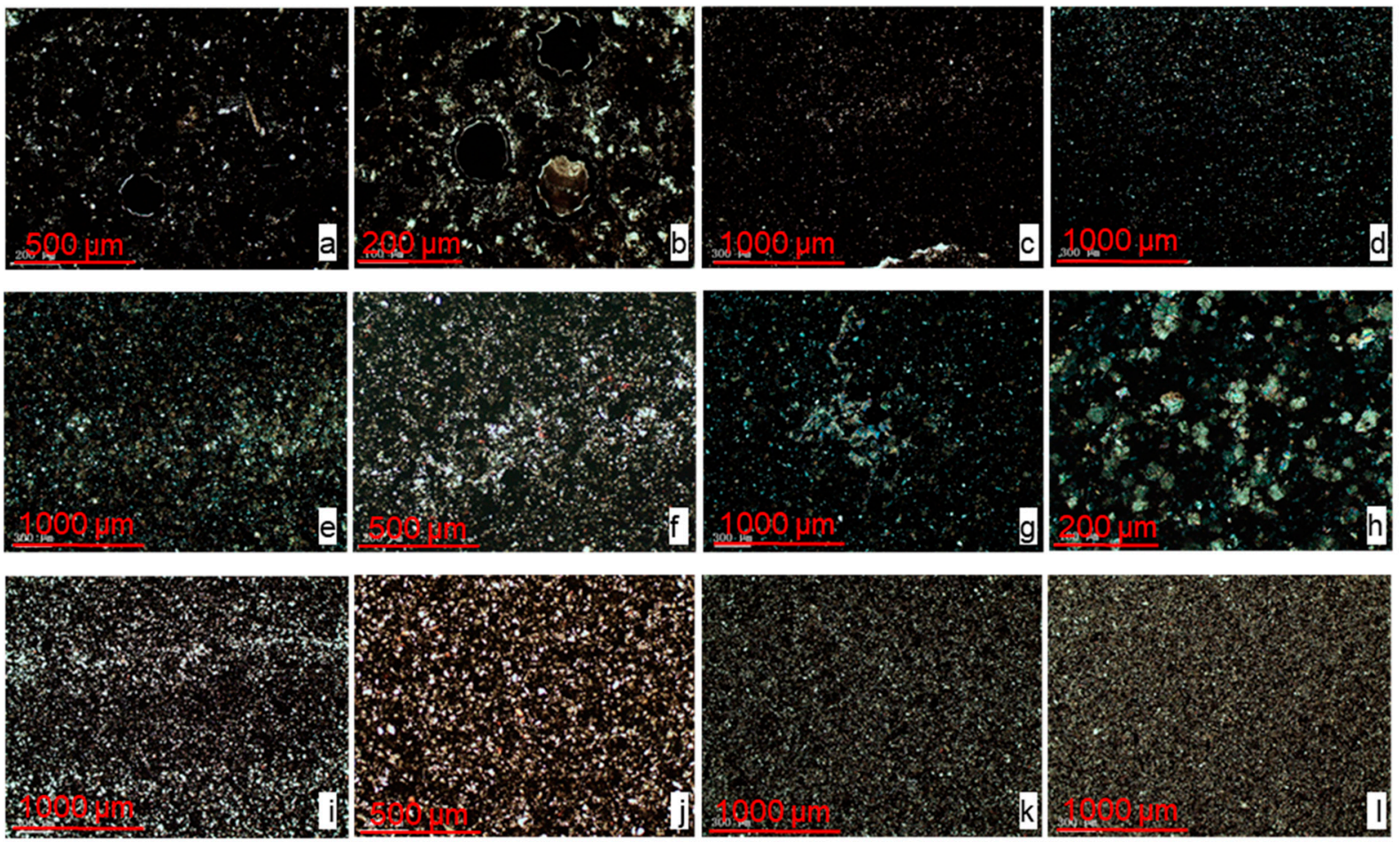

Figure 5. Microphotographs of rock thin sections in Wufeng-Longmaxi Formation from Well A. (a,b): carbonaceous siliceous shale, quartz with biological structure, radiolaria; (c,d): carbonaceous argillaceous shale, uniform; (e,f): composite shale, horizontal lamination; (g,h): composite shale, uniform; (i): silty shale, silty lamination; (j): silty shale; (k,1): argillaceous shale, uniform.

Table 3. Classification standards of lithofacies.

\begin{tabular}{ccccccc}
\hline \multirow{2}{*}{ Types of Lithofacies } & \multicolumn{3}{c}{ Standards of Classification } \\
\cline { 2 - 7 } & Quartz (\%) & $\begin{array}{c}\text { Clay Minerals } \\
\mathbf{( \% )}\end{array}$ & $\begin{array}{c}\text { Carbonate } \\
\mathbf{( \% )}\end{array}$ & $\begin{array}{c}\text { TOC } \\
\mathbf{( \% )}\end{array}$ & Biomass & Sedimentary Structure \\
\hline Carbonaceous siliceous shale & $>50$, biogenetic origin & $<50$ & $<10$ & $3-4$ & massive & horizontal lamination \\
\hline Carbonaceous argillaceous shale & $30-50$ & $40-60$ & $<10$ & $2-3$ & common & uniform \\
\hline Composite shale & $30-40$ & $30-40$ & $30-40$ & $1-2.5$ & few & uniform \\
\hline Silty shale & $>50$, terrestrial origin & $<50$ & $<10$ & $1-2$ & rare & horizontal band \\
\hline Argillaceous shale & $30-40$ & $>50$ & $<10$ & $\sim 1$ & few & uniform \\
\hline
\end{tabular}


Carbonaceous siliceous shale (LF1): The color was normally dark grey-black in this lithofacies. The quartz content was close to or $>50 \%$ and was mainly of a biogenetic origin, whereas the content of clay minerals and carbonate minerals was very low (Figures 3 and $5 a, b)$. The organic matter content was high (TOC 3-4\%) with massive fossils of graptolites. Horizontal laminations occurred frequently in LF1, which was mainly deposited during the transgression stage and was found to be distributed in the Wufeng Formation and lower member of the Longmaxi Formation (Figure 3).

Carbonaceous argillaceous shale (LF2): The color of this lithofacies was dark greyblack. The quartz content was normally between $30 \%$ and $50 \%$, whereas the TOC content ranged from $2 \%$ to $3 \%$ (Figures 3 and $5 \mathrm{c}, \mathrm{d}$ ). LF2 was mainly deposited during the transgression stage and was found to be distributed in the lower member of the Longmaxi Formation (Figure 3).

Composite shale (LF3): The color of this shale was dark grey. The contents of silicate, clay minerals and carbonate minerals in this lithology were relatively similar (Figures 3 and $5 \mathrm{e}-\mathrm{h}$ ). The organic matter content (TOC 1.0-2.5\%) was lower in comparison to LF1 and LF2. LF3 was mainly deposited during the stage of the early high-stand system tract and was observed to be distributed in the middle and upper members of the Longmaxi Formation (Figure 3).

Silty shale (LF4): The color of this lithofacies was dark grey. The quartz was derived from terrestrial silty particles and the content of clay minerals was $<50 \%$ (Figures 3 and $5 i, j$ ). Graptolites fossils were scarce and the TOC content ranged from $1.0 \%$ to $2.0 \%$. Silty bands or horizontal layers can be found in LF4. This was mainly deposited during the stage of the late high-stand system tract and was found to be distributed in the middle and upper member of the Longmaxi Formation (Figure 3).

Argillaceous shale (LF5): The color of this shale was dark grey. The content of clay minerals was between $40 \%$ and $50 \%$, whereas the contents of carbonate minerals were relatively low (Figures 3 and $5 k, 1$ ). The TOC content was about $1 \%$ and only a few fossils (e.g., graptolites) were found. LF5 was mainly deposited during the stage of the late high-stand system tract and was observed to be distributed in the upper member of the Longmaxi Formation (Figure 3).

\subsection{Types of Sedimentary Microfacies}

In combination with information regarding the regional geological background, lithofacies, and symbols of sedimentary facies, the WLBS was divided into 4 types of sedimentary microfacies as follows (Table 4).

Table 4. Classification standards of sedimentary microfacies.

\begin{tabular}{|c|c|c|c|c|c|}
\hline \multirow{2}{*}{$\begin{array}{l}\text { Sedimentary } \\
\text { Subfacies }\end{array}$} & \multirow{2}{*}{$\begin{array}{l}\text { Sedimentary } \\
\text { Microfacies }\end{array}$} & \multicolumn{4}{|c|}{ Standards of Classification } \\
\hline & & $\begin{array}{l}\text { Sedimentary } \\
\text { Structure }\end{array}$ & Fossils & logging Curves & Lithofacies \\
\hline \multirow[b]{2}{*}{ Deep shelf } & $\begin{array}{c}\text { Carbonaceous } \\
\text { siliceous deep shelf }\end{array}$ & \multirow{2}{*}{$\begin{array}{l}\text { horizontal lamination, } \\
\text { uniform, silty } \\
\text { lamination is rare }\end{array}$} & \multirow{2}{*}{$\begin{array}{c}\text { radiolaria, } \\
\text { siliceous sponge } \\
\text { spicules, massive } \\
\text { graptolites }\end{array}$} & \multirow[b]{2}{*}{ serrated flat curves } & $\begin{array}{l}\text { Carbonaceous } \\
\text { siliceous shale }\end{array}$ \\
\hline & $\begin{array}{l}\text { Carbonaceous } \\
\text { argillaceous shale }\end{array}$ & & & & $\begin{array}{l}\text { Carbonaceous } \\
\text { argillaceous shale } \\
\text { Composite shale }\end{array}$ \\
\hline \multirow{2}{*}{ Shallow shelf } & $\begin{array}{l}\text { Silty argillaceous } \\
\text { shallow shelf }\end{array}$ & \multirow{2}{*}{$\begin{array}{l}\text { parallel bedding, silty } \\
\text { laminations and } \\
\text { lenticles are common }\end{array}$} & \multirow{2}{*}{$\begin{array}{l}\text { brachiopods, coral, } \\
\text { graptolite is scarce }\end{array}$} & \multirow{2}{*}{$\begin{array}{c}\text { funnelled and } \\
\text { bell-shaped curves }\end{array}$} & $\begin{array}{c}\text { Silty shale } \\
\text { Argillaceous shale }\end{array}$ \\
\hline & $\begin{array}{l}\text { Argillaceous } \\
\text { shallow shelf }\end{array}$ & & & & Argillaceous shale \\
\hline
\end{tabular}

Carbonaceous siliceous deep shelf (SMF1): This microfacies mainly consisted of LF1 and was mainly developed in the Wufeng Formation and lower member of the Longmaxi Formation (Figure 3). The sedimentary environment was strongly anoxic with high sea- 
level, which was evident from the occurrence of frequent pyrite bands and aggregations.

Carbonaceous argillaceous deep shelf (SMF2): This microfacies mainly consisted of LF2 and LF3, and was mainly developed in the lower member of Longmaxi Formation (Figure 3). The sedimentary environment was mainly anoxic as there was a decreased sea-level in comparison to SMF1.

Silty argillaceous shallow shelf (SMF 3): This microfacies mainly consisted of LF4 interbedded with some of LF5, and was developed in the middle and upper members of the Longmaxi Formation (Figure 3). The sedimentary environment was mainly oxidizing due to a low sea-level.

Argillaceous shallow shelf (SMF4): This microfacies mainly consisted of LF5 interbedded with some of LF4, and was mainly developed in the middle and upper member of the Longmaxi Formation (Figure 3). The sedimentary environment was mainly oxicanoxic with low sea level.

\subsection{Characteristics of Organic Geochemistry}

Remarkable differences in organic matter content were observed among the different sedimentary microfacies (Figure 6), whereby the TOC values in SMF1 were normally $>4 \%$, whereas those in SMF2 were between $2 \%$ and $4 \%$, and those in SMF3 and SMF4 were mostly $<2 \%$. Generally, the shale in SMF1 (followed by SMF2) was beneficial for the accumulation of organic matter, whereas the shale in SMF3 and SMF4 was not.

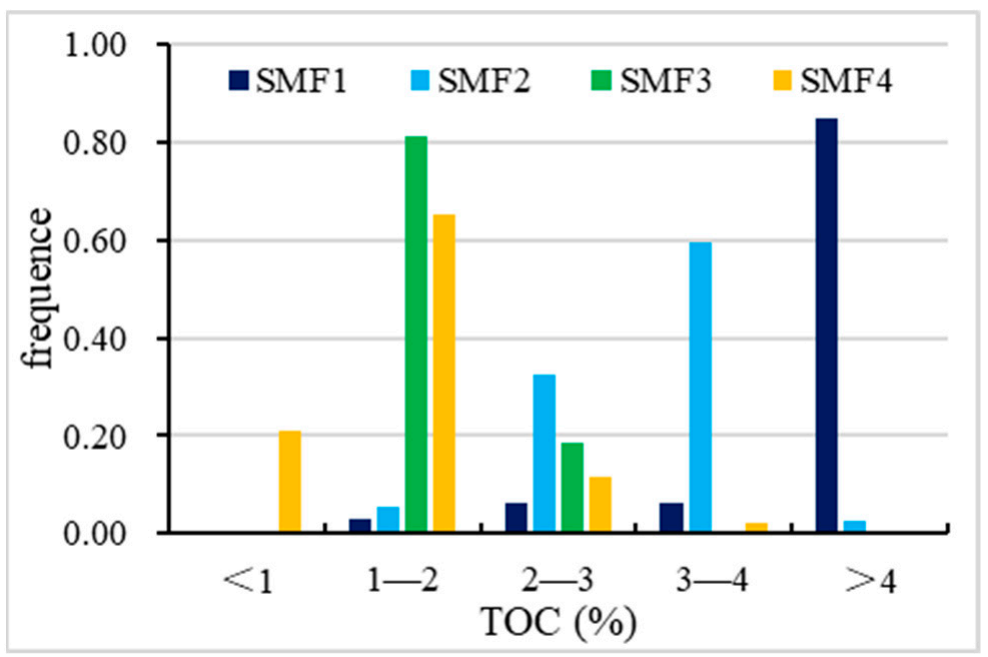

Figure 6. Distribution of total organic carbon (TOC) in different sedimentary microfacies of WufengLongmaxi Formation in Well A. SMF: sedimentary microfacies.

The accumulation of organic matter in marine shale is the result of various factors in the sedimentary environment. It is generally believed that the main controlling factors of organic matter accumulation are preservation condition (anoxic bottom water) and high primary productivity $[29,30]$. Previous studies suggested that large-scale transgression occurred during the Early Silurian due to the melting of glaciers, which caused a severe ocean anoxic event [31,32]. The SMF1 at the bottom of the Longmaxi Formation existed in the transgression systems tract with a strongly reducing environment, thus resulting in a large amount of organic matter preservation. Subsequently, the oxygen content in the bottom water gradually increased due to decreasing sea level; therefore, the organic matter in SMF2, SMF3, and SMF4 decreased accordingly.

Previous studies suggested that the WLBS experienced a long burial period, and that multiple periods of tectonic evolution occurred in the Sichuan Basin, which have resulted in the deep burial depth of the WLBS. Other studies reported that Ro values ranged between $2.4 \%$ and $4.0 \%$, indicating the organic matter was over-mature [33,34]. In this study, Ro values from eight samples in Well A ranged from $2.2 \%$ to $3.13 \%$ and indicate that the 
organic matter was also in the stage of high -over maturity in study area, as well (Figure 3, Table 1). Both $\delta^{13} \mathrm{C}$ values for kerogen from Well A were $>-29 \%$ (Table 1), thus implying that the kerogens in the WLBS are sapropel (type I), as based on comparing them with the classification standard of kerogen type (Huang et al., 1984). Moreover, the microscope images of extracted kerogens also evidenced that the organic matter was flocculent sapropel derived from algae (Figure 7).
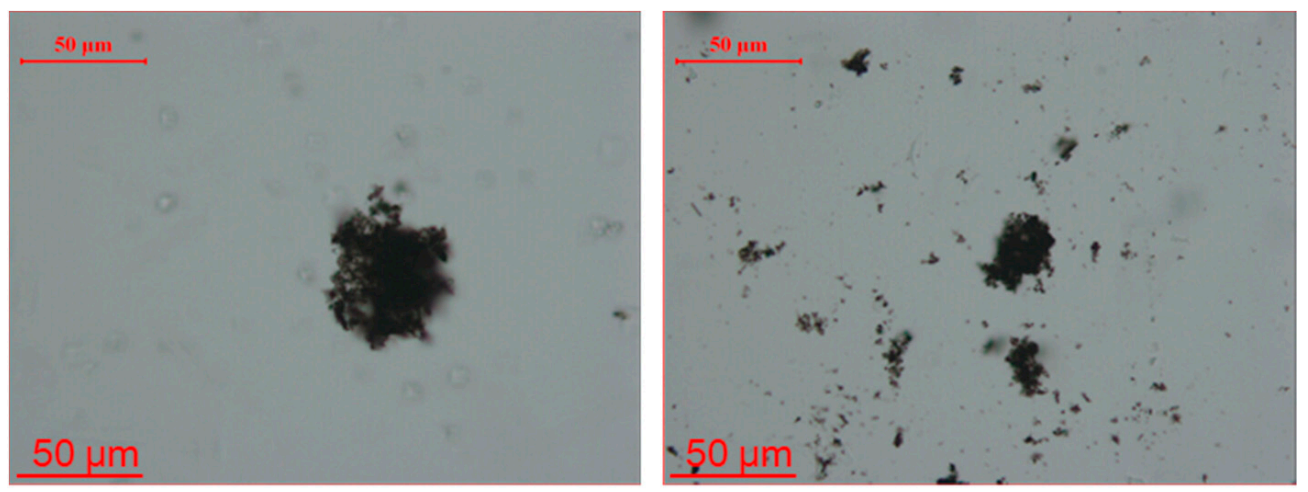

Figure 7. Microphotographs of kerogen of Wufeng-Longmaxi Formation in Well A.

\subsection{Physical Properties of Reservoir}

\subsubsection{Types of Pores in Reservoir}

In this study, massive SEM images of the WLBS were observed to classify the types of pores on the basis of pore origins. By analyzing the origins of the pores, the pores could be divided into 5 types.

Organic pore: Shapes were observed to be largely irregular, spherical, or slit, and diameters were mainly in nanoscale. The organic pores formed during the hydrocarbon generation in organic matter attached among the inorganic particles (Figure $8 \mathrm{a}, \mathrm{b}$ ). This type of pore is abundant in LF1-2 and SMF1-2, where organic matter was rich and hydrocarbons were readily generated.

Interbedded pore of clay minerals: Shapes were observed to be mostly plate-like, layered, reticulate, linear, or irregular, and diameters ranged from hundreds of nanometers to the millimeter level. These pores were mainly generated between layers of clay minerals such as illite or chlorite during the process of diagenetic transformation or alteration (Figure 8c,d). This type of pore is abundant in LF5 and SMF4, in which the contents of clay minerals were relative high.

Intergranular pore: Shapes were observed to be largely triangular, polygonal, or irregular, and diameters were in nanoscale. Intergranular pores were mainly residual primary pores after diagenetic compaction, and were mostly found among particles of quartz, feldspar, and clay minerals (Figure 8e,f). This type of pore could be found in all the lithofacies and microfacies.

Intragranular pore: Shapes were observed to be mostly elliptic, linear, or irregular, and diameters were in nanoscale. Intragranular pores were mainly formed by diagenesis (e.g., transformation, alteration, and dissolution) in particles of quartz, feldspar, calcite, apatite, and other minerals (Figure $8 \mathrm{~g}-\mathrm{i}$ ). This type of pore could be found in all the lithofacies and microfacies.

Microfractures: Shapes were observed to be largely linear and serrated, and lengths ranged from hundreds of nanometers to the millimeter level. These microfractures were formed by 3 origins: (1) tensile microfractures generated under tectonic activities; (2) microfractures around rigid particles that were formed by the shrinkage of mineral particles during diagenesis; and (3) microfractures in organic matter that were formed due to the overpressure during hydrocarbon generation (Figure 8j-1). The tensile microfractures and microfractures around rigid particles appear occasionally, and the microfractures in organic matter occur frequently in LF1-2 and SMF1-2. 

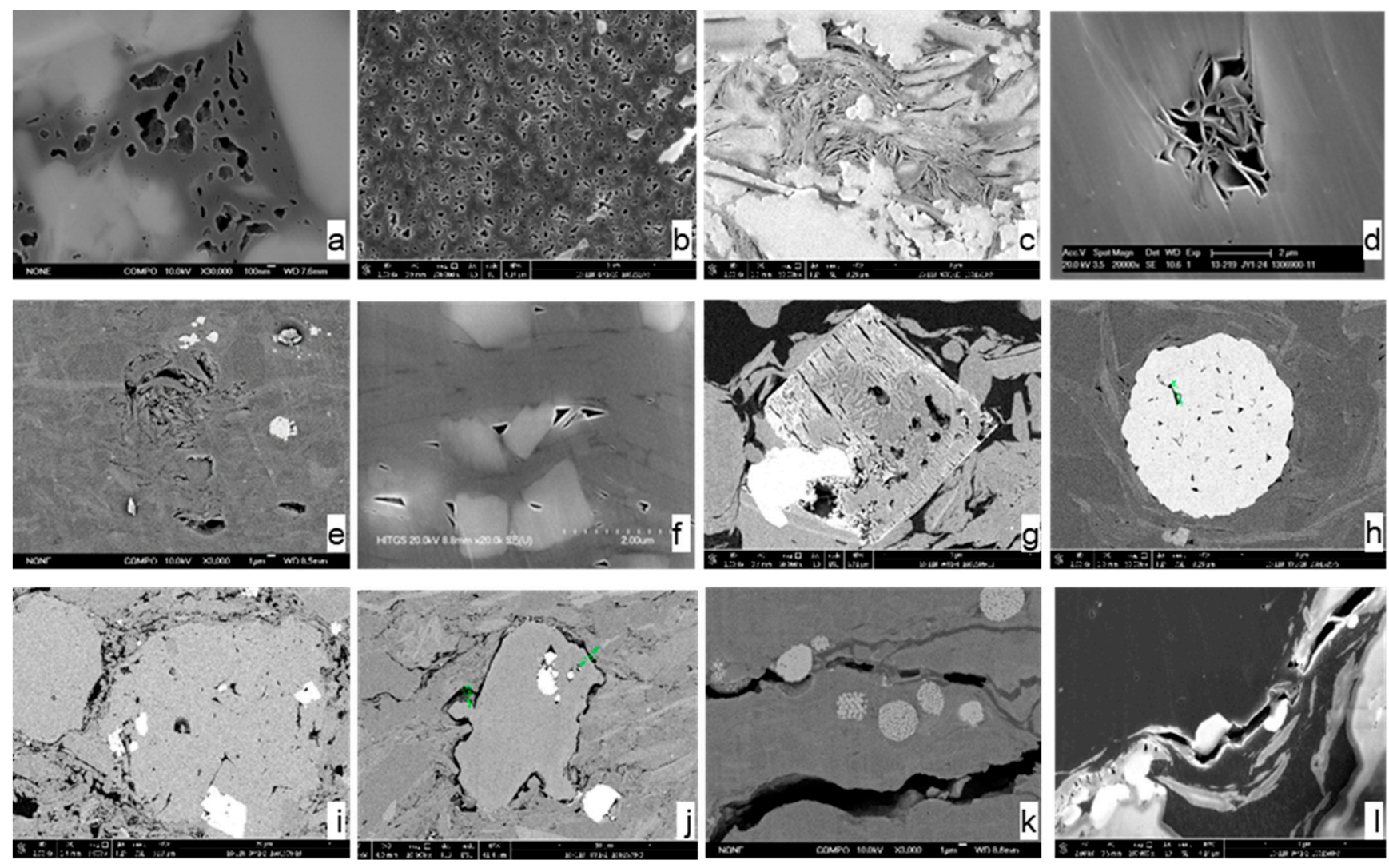

Figure 8. Scanning electron microscope (SEM) photographs of pores in reservoir of Wufeng-Longmaxi Formation in Sichuan Basin. $(\mathbf{a}, \mathbf{b})$ : organic pores; $(\mathbf{c}, \mathbf{d})$ : interbedded pores of clay minerals; (e,f): intergranular pores; (g): intragranular pores of feldspar dissolution; (h): intragranular pores among pyrite crystals; (i): intragranular pores of quartz dissolution; (j): microfractures around rigid particles; $(\mathbf{k}, \mathbf{l})$ : microfractures in organic matter.

\subsubsection{Porosity and Permeability}

The porosity of the lower member of the WLBS was mostly between $4 \%$ and $6 \%$, whereas that of the middle member of the WLBS was generally $<4 \%$ and that of the upper member of the WLBS was between $4 \%$ and $8 \%$ (Figure 3). The variation of permeability was relatively larger $(0.0015-335.21 \mathrm{mD})$ due to microfractures in some samples (Figure 3), which provided infiltration channels conducive to shale gas production.

Overall, porosity showed a positive relationship with TOC, in which the Pearson correlation coefficient is 0.5725 (Figure 9a), which indicated the increase of organic pores make the porosity increase simultaneously. The upper member of the WLBS had a high porosity, low TOC, and high content of clay minerals, thus implying that the interbedded pores of clay minerals contribute to massive pores. Furthermore, porosity was positively correlated with Ro values, in which the Pearson correlation coefficient is 0.7589 (Figure 9b), which indicated that pores in the shale reservoir gradually increased with the advancement of thermal evolution.

\subsubsection{Pore Structure}

The 3D-FIB images provide a method of visually observing the characteristics of nanopores above $1.0 \mathrm{~nm}$, and were performed for shale samples from the WLBS in the Nanchuan area of the Sichuan Basin. The images showed that the organic nanopores were extremely abundant and had a good connectivity (Figure 10). Through statistical analysis of more than 4000 organic pores in each sample, the majority of pores were $<10 \mathrm{~nm}$ in width (Figure 10). The number of pores $>100 \mathrm{~nm}$ in width increased significantly in the upper member of the Longmaxi Formation (Figure 10i) in comparison to that of the bottom of the Longmaxi Formation and the Wufeng Formation (Figure 10c,f,i). 

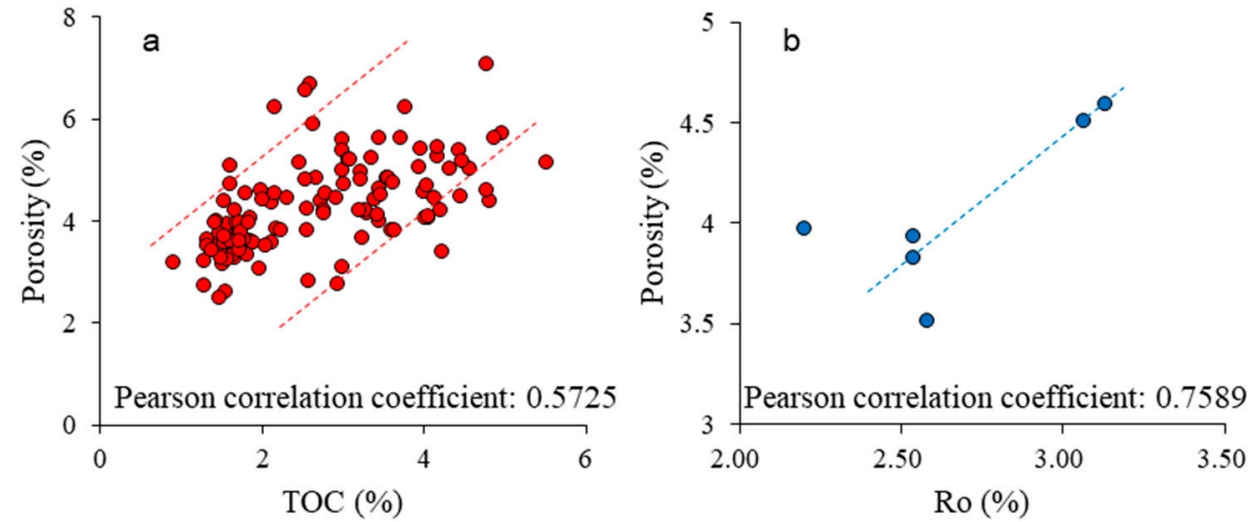

Figure 9. Relationship between (a) porosity and total organic carbon (TOC), (b) porosity and vitrinite reflectance (Ro) of Wufeng-Longmaxi Formation in Well A.
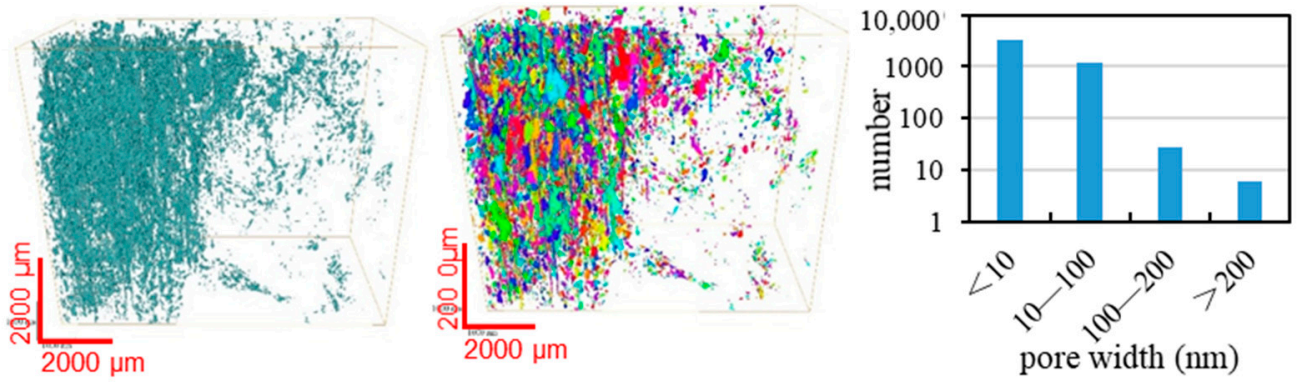

a. organic pore distribution
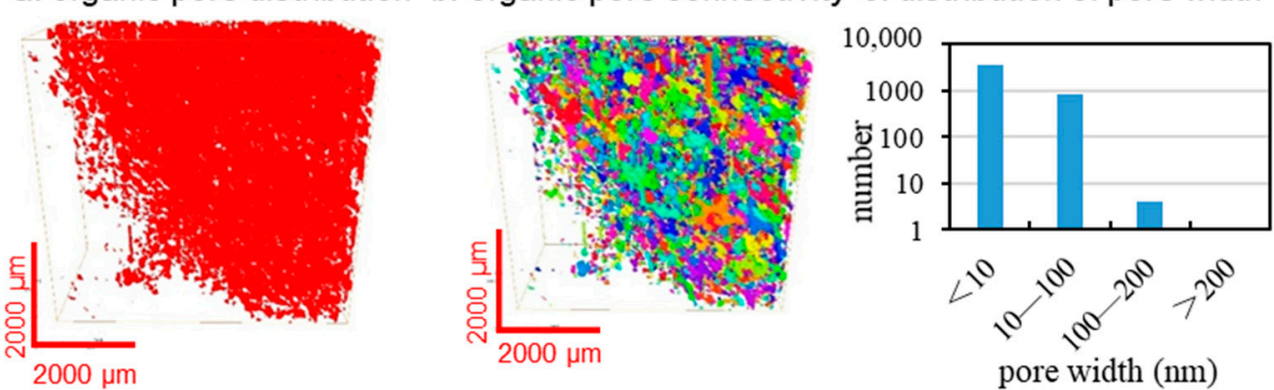

d. organic pore distribution
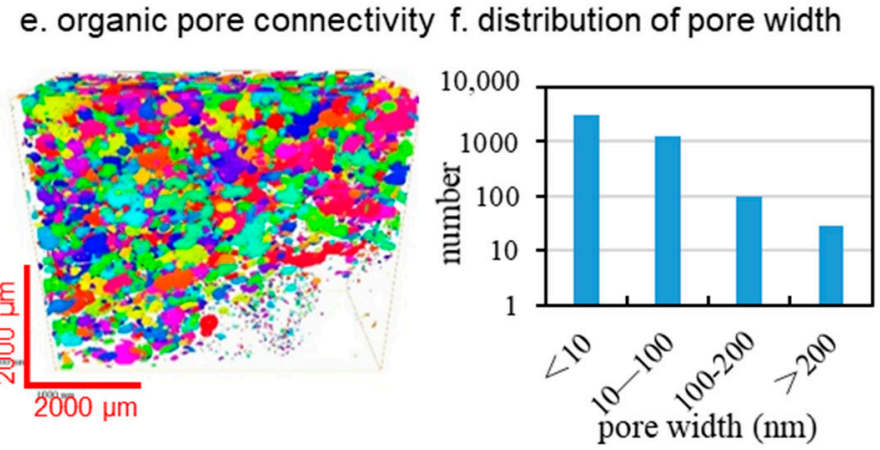

g. organic pore distribution h. organic pore connectivity i. distribution of pore width

Figure 10. Three-dimensional focused ion beam (3D-FIB) microphotographs and statistical data of Wufeng-Longmaxi Formation in Sichuan Basin. (a-c): Wufeng Formation; $(\mathbf{d}-\mathbf{f})$ : lower member of Longmaxi Formation; (g-i): upper member of the Longmaxi Formation.

\subsection{Gas Content of Shale}

The results of the gas adsorption analysis for samples from Well A revealed that the adsorption capacity of methane (calculated by the Langmuir equation) was between $1.72 \mathrm{~m}^{3} / \mathrm{t}$ and $4.66 \mathrm{~m}^{3} / \mathrm{t}$ (Table 2, Figure 11), which gradually decreased from the bottom 
upwards (Figure 3). By contrast, the geological factors of WLBS, e.g., thickness, depth, organic matter, thermal maturity and mineral components, are similar to the Marcellus shale in the Appalachia Basin in North America and lower Cambrian shale (Qiongzhousi Formation and its equivalent shale). Previous research suggested that organic matter played a major role in gas adsorption in shale reservoirs [23,24,35,36]. A large number of nanoscale pores were generated in organic matter, which would provide massive specific surface area for gas adsorption. The shale gas molecules mainly adsorbed on the pore surfaces. The quantities of gas adsorption and the TOC in the WLBS exhibited a clear positive relationship, in which the Pearson correlation coefficient was 0.9471 (Figure 12a), indicating that organic pores in the shale could provide abundant spaces for methane absorption and improve the capacity of gas absorption in the shale reservoir. Through statistical analysis of the gas volume and lost gas volume, the total gas content of the samples was found to be between $0.44 \mathrm{~m}^{3} / \mathrm{t}$ and $5.19 \mathrm{~m}^{3} / \mathrm{t}$ (Table 5 ), gradually decreasing from the bottom to the top (Figure 3). A positive correlation between the gas content and TOC, in which the Pearson correlation coefficient was 0.7663 , indicated that the organic pores provide the main storage space for shale gas in the study area, and the gas content increases sharply in TOC $>3.0 \%$ (Figure 12b). Therefore, the organic matter content of the WLBS is considered to be the most important factor influencing shale gas accumulation in the study area.

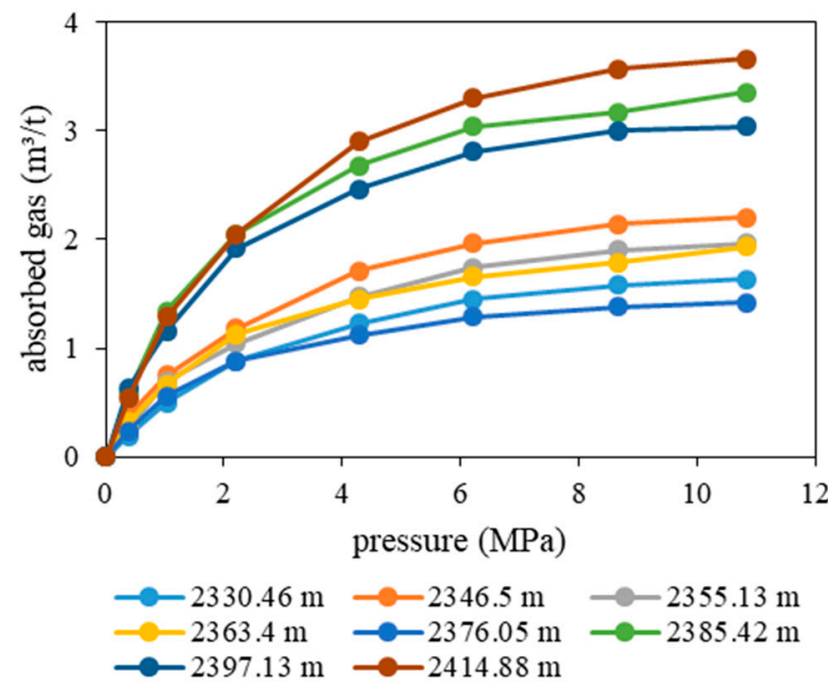

Figure 11. Methane absorption versus pressure of Wufeng-Longmaxi Formation in Well A.
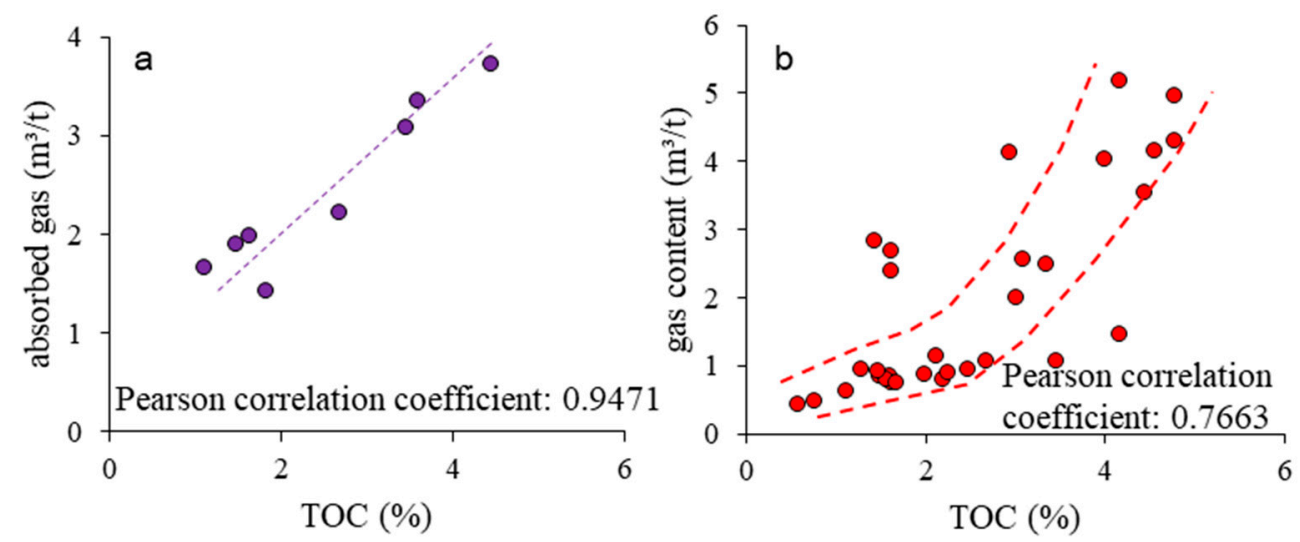

Figure 12. Relationship between (a) absorbed gas and total organic carbon (TOC), and (b) gas content and TOC of Wufeng-Longmaxi Formation in Well A. 
Table 5. Gas content data of Wufeng-Longmaxi Formation in Well A.

\begin{tabular}{|c|c|c|c|c|c|}
\hline Depth (m) & $\begin{array}{c}\text { Desorbed Temperature } \\
\left({ }^{\circ} \mathrm{C}\right)\end{array}$ & $\begin{array}{l}\text { Measured Gas } \\
\qquad\left(\mathrm{m}^{3} / \mathrm{t}\right)\end{array}$ & $\begin{array}{l}\text { Lost Gas } \\
\left(\mathrm{m}^{3} / \mathrm{t}\right)\end{array}$ & $\begin{array}{l}\text { Residual Gas } \\
\qquad\left(\mathrm{m}^{3} / \mathrm{t}\right)\end{array}$ & $\begin{array}{c}\text { Total Gas Content } \\
\left(\mathrm{m}^{3} / \mathrm{t}\right)\end{array}$ \\
\hline 2330.44 & 62.3 & 0.44 & 0.15 & 0.04 & 0.63 \\
\hline 2334.07 & 62.5 & 0.32 & 0.14 & 0.01 & 0.47 \\
\hline 2336.35 & 62.5 & 0.31 & 0.11 & 0.02 & 0.44 \\
\hline 2340.61 & 62.5 & 0.65 & 0.16 & 0.04 & 0.84 \\
\hline 2342.45 & 62.7 & 0.69 & 0.15 & 0.04 & 0.88 \\
\hline 2346.35 & 62.7 & 0.82 & 0.24 & 0.01 & 1.08 \\
\hline 2348.57 & 62.7 & 0.64 & 0.15 & 0.02 & 0.81 \\
\hline 2353.03 & 62.8 & 0.66 & 0.24 & 0.06 & 0.95 \\
\hline 2355.29 & 62.8 & 0.55 & 0.14 & 0.06 & 0.76 \\
\hline 2357.43 & 62.8 & 0.68 & 0.16 & 0.01 & 0.86 \\
\hline 2357.72 & 62.8 & 0.61 & 0.16 & 0.03 & 0.8 \\
\hline 2359.73 & 63 & 0.51 & 0.18 & 0.05 & 0.74 \\
\hline 2363.49 & 63 & 0.64 & 0.25 & 0.04 & 0.92 \\
\hline 2366.75 & 63 & 0.73 & 0.37 & 0.04 & 1.14 \\
\hline 2369.76 & 63.2 & 0.58 & 1.73 & 0.06 & 2.38 \\
\hline 2372.71 & 63.2 & 0.72 & 1.91 & 0.06 & 2.69 \\
\hline 2373.04 & 63.2 & 0.72 & 2.06 & 0.05 & 2.83 \\
\hline 2378.33 & 63.4 & 0.62 & 0.29 & 0.04 & 0.94 \\
\hline 2381.8 & 63.4 & 0.85 & 1.11 & 0.03 & 2 \\
\hline 2383.6 & 63.4 & 1.01 & 1.47 & 0.02 & 2.5 \\
\hline 2387.55 & 63.6 & 1.19 & 2.81 & 0.04 & 4.04 \\
\hline 2391.91 & 63.6 & 1.05 & 1.48 & 0.05 & 2.57 \\
\hline 2392.75 & 63.8 & 0.6 & 0.22 & 0.07 & 0.89 \\
\hline 2397.17 & 63.8 & 0.75 & 0.3 & 0.02 & 1.08 \\
\hline 2399.59 & 63.8 & 1.06 & 0.37 & 0.04 & 1.47 \\
\hline 2402.58 & 63.9 & 0.94 & 3.15 & 0.06 & 4.14 \\
\hline 2404.55 & 63.9 & 1.26 & 2.85 & 0.04 & 4.15 \\
\hline 2406.27 & 63.9 & 1.12 & 3.79 & 0.06 & 4.96 \\
\hline 2406.56 & 63.9 & 1.27 & 3.9 & 0.02 & 5.19 \\
\hline 2412.19 & 64 & 1.4 & 2.85 & 0.06 & 4.31 \\
\hline 2414.9 & 64 & 1.09 & 2.4 & 0.06 & 3.55 \\
\hline
\end{tabular}

\subsection{Coupling between Source Rock and Reservoir of Shale Gas}

As the hydrocarbon source, both the gas potential and the gas amount of shale are determined by the organic matter content of shale $[4,5,37,38]$. Meanwhile, shale also acts as a reservoir for shale gas [39]; thus, the reservoir capacity of shale is crucial for the enrichment of shale gas, especially the characteristics of the organic pores, which determine the adsorption and preservation of shale gas $[37,38]$. The WLBS contains massive rigid mineral granules (such as quartz and feldspar) forming intergranular spaces, where organic matters could be stored during the period of hydrocarbon generation. The WLSB in Sichuan Basin has undergone a long history of evolution, resulting in the high thermal maturity of organic matters. It has been proved above that the high content of organic matter in WLBS was favorable for the shale gas accumulation. The WLBS has high thermal maturity due to the high values of Ro, resulted in abundant pores existing in organic matter. The pores in the organic matter of WLBS provide an important adsorbent of absorbed gas and spaces for free gas. For this reason, the degree of organic matter pore development controls the ability to store natural gas. Therefore, the shale in the carbonaceous siliceous/argillaceous deep shelf in the lower member of WLBS with high TOC is considered to have both a strong hydrocarbon generation potential and storage capacity for shale gas, resulting in high gas content. However, the upper member of the WLBS was found to have a low TOC content and thus low gas content, although porosity was determined to be high. Overall, the shale gas would be accumulated under both favorable conditions of source rock and reservoir in the shale. 


\section{Conclusions}

(1) The most important mineral in Wufeng-Longmaxi Formation is quartz followed by clay minerals, with a small amount of carbonate minerals and feldspar. The shale of Wufeng-Longmaxi Formation in the Sichuan Basin was divided into 5 types of lithofacies (carbonaceous siliceous shale, carbonaceous argillaceous shale, composite shale, silty shale, and argillaceous shale) and 4 types of sedimentary microfacies (carbonaceous siliceous deep-shelf, carbonaceous argillaceous deep-shelf, silty argillaceous shallow-shelf, and argillaceous shallow-shelf).

(2) The values of TOC in Wufeng-Longmaxi Formation basically ranged from $0.5 \%$ to $6.0 \%$ (about $2.54 \%$ on average), and gradually decreased vertically from the bottom to the top, which was controlled by the oxygen content of the bottom water. The organic matter in it was mainly sapropel with high maturity.

(3) The shale reservoir of Wufeng-Longmaxi Formation was found to be characterized by low porosity and low permeability. The types of pore include organic pore, interbedded pore of clay minerals, intergranular pore, intragranular pore, microfractures. The pore types were mainly $<10 \mathrm{~nm}$ organic pores, especially in the lower member of the Longmaxi Formation. Inorganic pores were observed to increase sharply in the upper member of the Longmaxi Formation.

(4) The volumes of methane adsorption were between $1.431 \mathrm{~m}^{3} / \mathrm{t}$ and $3.719 \mathrm{~m}^{3} / \mathrm{t}$ and the total gas content of samples were distributed between $0.44 \mathrm{~m}^{3} / \mathrm{t}$ and $5.19 \mathrm{~m}^{3} / \mathrm{t}$, both of which gradually decreased from the bottom upwards. This indicates that lower member of Wufeng-Longmaxi Formation possessed stronger capacity for gas absorption and storage than the upper member.

(5) The pores in the organic matter of the Wufeng-Longmaxi Formation provide important spaces for absorbed gas and free gas. Shale with high TOC content in the carbonaceous siliceous/argillaceous deep-shelf lithofacies is considered to have favorable hydrocarbon generation potential and storage capacity, providing favorable conditions of the source rock and reservoir for shale gas.

Author Contributions: Conceptualization, Y.Z. and Z.H.; methodology, S.J.; software, Y.Z.; validation, Z.H. and S.J.; formal analysis, Y.L.; investigation, Y.L.; resources, Z.H. and D.X.; data curation, D.X.; writing-original draft preparation, Y.Z.; writing-review and editing, Y.Z.; visualization, J.Z. and G.C.; supervision, Z.H.; project administration, Z.H. and J.Z.; funding acquisition, Y.Z. All authors have read and agreed to the published version of the manuscript.

Funding: This research was funded by the [National Natural Science Foundation Research] grant number [41902127, 41802157], and the [Shandong Provincial Natural Science Foundation, China] grant number [ZR2018BD015], the [Fundamental Research Funds for the Central Universities, China University of Geosciences (Wuhan)] grant number [CUG2106327].

Institutional Review Board Statement: Not applicable.

Informed Consent Statement: Informed consent was obtained from all subjects involved in the study.

Data Availability Statement: The data presented in this study are available in article.

Conflicts of Interest: The authors declare no conflict of interest.

\section{References}

1. Lüning, S.; Craig, J.; Loydell, D.K.; Štorch, P.; Fitches, B. Lower Silurian 'hot shales' in North Africa and Arabia: Regional distribution and depositional model. Earth Sci. Rev. 2000, 49, 121-200. [CrossRef]

2. Yan, C.; Jin, Z.; Zhao, J.; Du, W.; Liu, Q. Influence of sedimentary environment on organic matter enrichment in shale: A case study of the Wufeng and Longmaxi Formations of the Sichuan Basin, China. Mar. Pet. Geol. 2018, 92, 880-894. [CrossRef]

3. Zhang, T.; Trela, W.; Jiang, S.-Y.; Nielsen, J.K.; Shen, Y. Major oceanic redox condition change correlated with the rebound of marine animal diversity during the Late Ordovician. Geology 2011, 39, 675-678. [CrossRef]

4. He, Z.; Nie, H.; Zhang, Y. He main factors of shale gas enrichment of Ordovician Wufeng Formation-Silurian Longmaxi Formation in the Sichuan Basin and its adjacent area. Earth Sci. Front. 2016, 23, 8-17. (In Chinese with an English abstract)

5. Jin, Z.; Hu, Z.; Gao, B.; Zhao, J. Controlling factors on the enrichment and high productivity of shale gas in the Wufeng-Longmaxi Formations,southeastern Sichuan Basin. Earth Sci. Front. 2016, 23, 1-7. (In Chinese with an English abstract) 
6. Zou, C.; Yang, Z.; Dai, J.; Dong, D.; Zhang, B.; Wang, Y.; Deng, S.; Huang, J.; Liu, K.; Yang, C. The characteristics and significance of conventional and unconventional Sinian-Silurian gas systems in the Sichuan Basin, central China. Mar. Pet. Geol. 2015, 64, 386-402. [CrossRef]

7. Chen, X.; Fan, J.; Zhang, Y.D.; Wang, H.Y.; Chen, Q.; Wang, W.H.; Liang, F.; Guo, W.; Zhao, Q.; Nie, H. Subdivision and Delineation of the Wufeng and Lungmachi Black Shales inthe Subsurface Areas of the Yangtze Platform. J. Stratigr. 2015, 39, 351-358, (In Chinese with an English abstract).

8. Chen, X.; Fan, J.; Wang, W.; Wang, H.; Nie, H.; Shi, X.; Wen, Z.; Chen, D.; Li, W. Stage-progressive distribution pattern of the Lungmachi black graptolitic shales from Guizhou to Chongqing, Central China. Sci. China Earth Sci. 2017, 60, 1133-1146. [CrossRef]

9. Liang, D.; Guo, T.; Chen, J.; Bian, L.; Zhao, Z. Some progresses on studies of hydrocarbon generation and accumulation in marine sedimentary regions, southern China (Part 1): Distribution of four suits of regional marine source rocks. Mar. Orig. Pet. Geol. 2008, 13, 1-16. (In Chinese with an English abstract)

10. Bowker, K.A. Recent development of the Barnett Shale play, Fort Worth Basin. AAPG Bull. 2003, 42, 4-11.

11. Han, C.; Jiang, Z.; Han, M.; Wu, M.; Lin, W. The lithofacies and reservoir characteristics of the Upper Ordovician and Lower Silurian black shale in the Southern Sichuan Basin and its periphery, China. Mar. Pet. Geol. 2016, 75, 181-191. [CrossRef]

12. Zhang, Y.; He, Z.; Jiang, S.; Gao, B.; Liu, Z.; Han, B.; Wang, H. Marine redox stratification during the early Cambrian (ca. 529-509 $\mathrm{Ma}$ ) and its control on the development of organic-rich shales in Yangtze Platform. Geochem. Geophys. Geosyst. 2017, 18, 2354-2369. [CrossRef]

13. Chen, L.; Lu, Y.; Jiang, S.; Li, J.; Guo, T.; Luo, C. Heterogeneity of the Lower Silurian Longmaxi marine shale in the southeast Sichuan Basin of China. Mar. Pet. Geol. 2015, 65, 232-246. [CrossRef]

14. Chen, G.; Zhang, J.; Lu, S.; Pervukhina, M.; Dewhurst, D.N. Adsorption Behavior of Hydrocarbon on Illite. Energy Fuels 2016, 30, 9114-9121. [CrossRef]

15. Nie, H.; Jin, Z.; Zhang, J. Characteristics of three organic matter pore types in the Wufeng-Longmaxi Shale of the Sichuan Basin, Southwest China. Sci. Rep. 2018, 8, 7014. [CrossRef]

16. Zhang, Y.; He, Z.; Jiang, S.; Lu, S.; Xiao, D.; Chen, G.; Zhao, J. Factors Affecting Shale Gas Accumulation in Overmature Shales Case Study from Lower Cambrian Shale in Western Sichuan Basin, South China. Energy Fuels 2018, 32, 3003-3012. [CrossRef]

17. Guo, T. Key geological issues and main controls on accumulation and enrichment of Chinese shale gas. Pet. Explor. Dev. 2016, 43, 349-359. [CrossRef]

18. Zhang, Y.; He, Z.; Jiang, S.; Lu, S.; Xiao, D.; Chen, G.; Li, Y. Fracture types in the lower Cambrian shale and their effect on shale gas accumulation, Upper Yangtze. Mar. Pet. Geol. 2019, 99, 282-291. [CrossRef]

19. Jarvie, D.M.; Hill, R.J.; Ruble, T.E.; Pollastro, R.M. Unconventional shale-gas systems: The Mississippian Barnett Shale of north-central Texas as one model for thermogenic shale-gas assessment. AAPG Bull. 2007, 91, 475-499. [CrossRef]

20. Loucks, R.G.; Ruppel, S.C. Mississippian Barnett Shale: Lithofacies and depositional setting of a deep-water shale-gas succession in the Fort Worth Basin, Texas. AAPG Bull. 2007, 91, 579-601. [CrossRef]

21. Curtis, M.E.; Cardott, B.J.; Sondergeld, C.H.; Rai, C.S. Development of organic porosity in the Woodford Shale with increasing thermal maturity. Int. J. Coal Geol. 2012, 103, 26-31. [CrossRef]

22. Hu, Z.; Du, W.; Peng, Y.; Zhao, J. Microscopic Pore Characteristics and the Source-Reservoir Relationship of Shale-A case study from the wufeng and longmaxi formations in southeast sichuan basin. Oil Gas Geol. 2015, 36, 1001-1008.

23. Zhang, Y.; He, Z.; Lu, S.; Jiang, S.; Xiao, D.; Long, S.; Gao, B.; Du, W.; Zhao, J.; Chen, G.; et al. Characteristics of microorganisms and origin of organic matter in Wufeng Formation and Longmaxi Formation in Sichuan Basin, South China. Mar. Pet. Geol. 2020, 111, 363-374. [CrossRef]

24. Basu, S.; Verchovsky, A.B.; Bogush, A.; Jones, A.P.; Jourdan, A.L. Stability of Organic Carbon Components in Shale: Implications for Carbon Cycle. Front. Earth Sci. 2019, 7, 297. [CrossRef]

25. Kang, J.; Sun, Y.; Men, Y.; Tian, J.; Yu, Q.; Yan, J.; Lin, J.; Liu, J. Shale gas enrichment conditions in the frontal margin of Dabashan orogenic belt, south China. J. Nat. Gas Sci. Eng. 2018, 54, 11-24. [CrossRef]

26. Gou, Q.; Xu, S.; Hao, F.; Zhang, B.; Li, Q. Quantitative calculated shale gas contents with different lithofacies: A case study of Fuling gas shale, Sichuan Basin, China. J. Nat. Gas Sci. Eng. 2020, 76, 103222. [CrossRef]

27. Chen, X.; Rong, J.Y.; Yue, L.; Boucot, A.J. Facies patterns and geography of the Yangtze region, South China, through the Ordovician and Silurian transition. Palaeogeogr. Palaeoclimatol. Palaeoecol. 2004, 204, 353-372.

28. Zhao, J.H.; Jin, Z.J.; Jin, Z.K.; Wen, X.; Yan, C.N. The Genesis of Quartz in Wufeng-Longmaxi Gas Shales, Sichuan Basin. Nat. Gas Geosci. 2016, 27, 377-386. (In Chinese with an English abstract)

29. Huc, A.Y.; Bertrand, P.; Stow, D.A.V.; Gayet, J.; Vandenbroucke, M. Organic sedimentation in deep offshore settings: The Quaternary sediments approach. Pet. Geol. 2001, 18, 513-517. [CrossRef]

30. Jenkyns, H.C. Geochemistry of oceanic anoxic events. Geochem. Geophys. Geosyst. 2010, 11, Q03004. [CrossRef]

31. Li, Y.; Zhang, T.; Ellis, G.S.; Shao, D. Depositional environment and organic matter accumulation of Upper Ordovician-Lower Silurian marine shale in the Upper Yangtze Platform, South China. Palaeogeogr. Palaeoclimatol. Palaeoecol. 2017, 466, 252-264. [CrossRef]

32. Yan, D.; Wang, H.; Fu, Q.; Chen, Z.; He, J.; Gao, Z. Geochemical characteristics in the Longmaxi Formation (Early Silurian) of South China: Implications for organic matter accumulation. Mar. Pet. Geol. 2015, 65, 290-301. [CrossRef] 
33. Dai, J.; Zou, C.; Liao, S.; Dong, D.; Ni, Y.; Huang, J.; Wu, W.; Gong, D.; Huang, S.; Hu, G. Geochemistry of the extremely high thermal maturity Longmaxi shale gas, southern Sichuan Basin. Org. Geochem. 2014, 74, 3-12. [CrossRef]

34. Ji, W.; Song, Y.; Rui, Z.; Meng, M.; Huang, H. Pore characterization of isolated organic matter from high matured gas shale reservoir. Int. J. Coal Geol. 2017, 174, 31-40. [CrossRef]

35. Chen, G.; Lu, S.; Zhang, J.; Xue, Q.; Han, T.; Xue, H.; Tian, S.; Li, J.; Xu, C.; Pervukhina, M. Keys to linking GCMC simulations and shale gas adsorption experiments. Fuel 2017, 199, 14-21. [CrossRef]

36. Chen, G.; Li, C.; Lu, S.; Guo, T.; Wang, M.; Xue, Q.; Zhang, T.; Li, Z.; Sun, Y.; Liu, J.; et al. Critical factors controlling adsorption capacity of shale gas in Wufeng-Longmaxi formation, Sichuan Basin: Evidences from both experiments and molecular simulations. J. Nat. Gas Sci. Eng. 2021, 88, 103774. [CrossRef]

37. Ross, D.J.K.; Bustin, R.M. The importance of shale composition and pore structure upon gas storage potential of shale gas reservoirs. Mar. Pet. Geol. 2009, 26, 916-927. [CrossRef]

38. Zhang, T.; Ellis, G.S.; Ruppel, S.C.; Milliken, K.; Yang, R. Effect of organic-matter type and thermal maturity on methane adsorption in shale-gas systems. Org. Geochem. 2012, 47, 120-131. [CrossRef]

39. Ma, L.; Thomas, S.; Dowey, P.J.; Yue, S.; Rutter, E.H.; Taylor, K.G.; Lee, P.D. Hierarchical integration of porosity in shales. Sci. Rep. 2018, 8, 1-14. [CrossRef] 